\title{
A INTERPRETAÇÃO MORAL DA CONSTITUIÇÃO NA PERSPECTIVA DE RONALD DWORKIN E JEREMY WALDRON
}

\author{
Antonia Georgelia Carvalho Frota* \\ Renata Albuquerque Lima**
}

\section{RESUMO}

$\mathrm{O}$ artigo trata de uma das principais tendências no debate do positivismo jurídico contemporâneo, o papel da jurisdição constitucional. Essa perspectiva será examinada a partir da teoria de Ronald Dworkin e de Jeremy Waldron, filósofos e teóricos do direito que tem concentrado esforços na elaboração de uma teoria do direito democrática, visando a concretização dos Direitos Fundamentais. Busca-se analisar essas contraposições adotadas e averiguar a função da Hermenêutica Constitucional para concretização dos Direitos Fundamentais. A metodologia adotada nesta pesquisa foi uma investigação doutrinária de precedentes e de normas, as quais serviram de sustentação para as observações elaboradas sobre a temática.

Palavras-Chave: Interpretação Judicial; Neoconstitucionalismo; Hermenêutica Constitucional; Jurisdição Constitucional; Direitos Fundamentais.

\section{THE MORAL INTERPRETATION OF THE CONSTITUTION IN THE PERSPECTIVE OF RONALD DWORKIN AND JEREMY WALDRON}

\begin{abstract}
This article talks about one of the main trends in the debate on contemporary legal positivism, the constitutional jurisdiction. This perspective will be examined based on the theory of Ronald Dworkin and Jeremy Waldron, philosophers and legal theorists who have concentrated efforts on the elaboration of a theory of democratic law, aiming at the realization of Fundamental Rights. It seeks to analyze these oppositions adopted and to investigate the role of Constitutional Hermeneutics for the realization of Fundamental Rights. The methodology adopted was a doctrinal investigation of precedents and norms, which served as support for the observations about the theme.
\end{abstract}

Keywords: Judicial Interpretation; Neoconstitutionalism; Constitutional Hermeneutics; Constitutional Jurisdiction; Fundamental Rights.

\section{INTRODUÇÃO}

A proteção aos direitos fundamentais produziu limitações indiscutíveis pelo Poder Público, de forma que, a princípio, o ordenamento jurídico procurava conservar a autonomia

\footnotetext{
* Mestranda em Direito pelo Centro Universitário Christus (UNICRHISTUS). Especialista em Direito Público com ênfase em gestão pública pelo Centro Educacional Damásio. E-mail: georgeliafc@ hotmail.com.

${ }^{* *}$ Pós-Doutora em Direito pela Universidade Federal de Santa Catarina. Doutora em Direito Constitucional pela UNIFOR. Professora da UNICHRISTUS. Professora da UVA. Coordenadora do Curso de Direito da Faculdade Luciano Feijão. E-mail: realbuquerque@yahoo.com.
} 
do cidadão diante do Estado. A imensa desproporção social passou a conceder a incumbência das contribuições culturais e socioeconômicas ao Estado, favorecendo os indivíduos de maneira que fosse possível garantir o adequado deleite dos direitos fundamentais.

Atualmente, estão sendo protegidos no Estado Democrático de Direito os direitos fundamentais, buscando assegurar a unicidade relacionada ao estudo sobre os valores morais no ordenamento jurídico, através de uma hermenêutica principiológica, onde a interpretação afasta a reprodução e passa a desenvolver a criação, caracterizando uma situação de aplicabilidade dos direitos fundamentais, objetivando à sua total solidificação.

Diante de casos difíceis, fica a questão em relação a qual instituição detém a melhor condição para resolver a querela e, portanto, para realizar a interpretação constitucional. Assim, é importante delimitar a melhor forma de compreensão e aplicação das normas constitucionais, por ser essencial para orientar a atividade jurisdicional constitucional.

Dworkin (2003) imputa uma interpretação construtiva em sua Teoria da Integridade, considerando a eficácia de progressão do Direito e o arcabouço institucional. Por esta ótica, levando em conta a coerência entre princípios, a interpretação judicial reconheceria direitos advindos da moral e da história.

Os que seguem a ideia dworkiana defendem que a integridade descarta subjetivismos advindos dos intérpretes. Na visão desses apoiadores, existira um estímulo para que suas précompreensões fossem questionadas pelos intérpretes. Nos moldes deste ponto de vista, buscando identificar, haveria uma solução correta para os casos levados a juízo.

Nos tempos modernos, Waldron (2003) tem deferido fervorosas críticas à atuação dos juízes em relação às decisões com base na moralidade política. Consoante o autor, os desacertos existentes tanto na política como na moral e no Direito aduzem a vulnerabilidade de se admitir a presença de objetividade nestas querelas.

Deste modo, Waldron (2003) evidencia o significado de leviandade nas deliberações judiciais relacionada às questões de política e moral, denominada de ilegitimidade política, imprevisibilidade e falta de razão.

Em se tratando de objetividade moral, tanto Dworkin como Waldron, consideram-na irrelevante. Para Dworkin (2005), é insignificante buscar considerações generalizadas que fundamentem a essência de que a moral é clara, objetiva, pois em sua concepção seja qual for a justificativa relacionada a isto é impreterivelmente moral, e a análise deve ser exercida por 
dentro da prática, e não por fora dela. No entanto, Dworkin (2003) defende que para uma benévola execução do Direito é necessário que os juízes utilizem argumentos morais.

Waldron (1999) aborda como irrisória a objetividade moral, ao considerar incongruências entre os juízes e entre a sociedade, como disseminadores de uma ilícita interpretação judicial relativa à moral.

Será abordada neste artigo a função que pode ser exercida pelo Poder Judiciário de maneira legítima em um Estado Democrático. O intuito é analisar se é conferido ao Poder Judiciário a função de protetor dos valores morais elencados na constituição ou se ele está limitado a preservar as vias democráticas, bem como cada uma das indagações presentes na controvérsia da interpretação moral constitucional.

Em um primeiro momento, será exposto um aparato sobre a interpretação moral constitucional. Em seguida, será apresentada a Teoria da Integridade de Dowrkin e, por fim, o Constitucionalismo Político de Waldron, com a finalidade de esclarecer as discordâncias em torno das decisões embasadas na moralidade.

A metodologia adotada nesta pesquisa foi uma investigação doutrinária de precedentes e de normas, as quais serviram de sustentação para as observações elaboradas sobre a temática. A revisão bibliográfica tem o propósito de explorar o entendimento de dois relevantes autores sobre a interpretação judicial constitucional relacionada à moral.

\section{A INTERPRETAÇÃO MORAL DA CONSTITUIÇÃO}

A Teoria do Direito vem apresentando uma certa relevância no contexto jurídico. Importante mencionar que a hermenêutica constitucional é a área que versa sobre a interpretação em essência. Os preceitos legais estão postos a serem interpretados em concordância com a constituinte. Como perfeitamente preceitua Gadamer (2003), a façanha de interpretar, concernente ao melhor entendimento do texto, corresponde à aplicação do direito.

A solidificação do texto constitucional é o encerramento do círculo hermenêutico ${ }^{1}$. De acordo com Canotilho (1998), a efetivação das normas constitucionais tem por finalidade a atividade interpretativa. Os métodos para a interpretação constitucional precisam ser

\footnotetext{
1 É uma maneira reflexiva de interpretarmos dados com base em outras informações. Refere-se a lógica interna da compreensão hermenêutica, ou seja, a regra segundo a qual é necessário compreender o todo de um texto a partir das suas partes e estas a partir do todo.
} 
apropriados à Teoria do Direito. E isso não afasta a possibilidade de haver a aplicação de mais de um método em uma mesma situação, em um mesmo fato.

A utilização do princípio da unidade constitucional, o qual preconiza a conexão e a interpretação das normas constitucionais, pode ser usado para exemplificar, visto que, buscando resolver discordâncias entre normas constitucionais, existem autores que fazem o uso da ponderação, como Humberto Ávila (2003), outros, como Barroso (2003), que operam com os princípios e ainda que utilizam as regras, como Jane Reis (2006).

Em se tratando de interpretação moral do texto constitucional, esta carece ser executada por juízes, em virtude de deliberarem, baseado em fundamentos de princípios, analisados como referência. Esta preferência, bem assevera Dworkin (2010), respaldada em princípios, se fundamenta na causa do seu fomento, distintamente acontece quando as soluções são arroladas com base em fundamentos políticos.

A problemática em optar pelo Poder Judiciário para ser o incumbido em efetivar a interpretação moral da Constituição, se depara com a possibilidade de o Direito permanecer sujeito aos princípios morais, os quais são utilizados pelo Judiciário, afastando da população, assim, a resolução de querelas relacionadas à moralidade política.

É imprescindível que tenha harmonia entre a defesa dos direitos individuais e o respeito aos anseios da população. Muitos juristas buscam obter uma possível interpretação constitucional que demande limitações na interpretação moral realizada pelo Judiciário. Argumentam não ser pertinente conferir exorbitante poder para os juízes.

O Estado Democrático de Direito busca garantir uma equidade material aos indivíduos, e não somente a simples equidade formal desprovida da apreciação de valor a respeito de seu argumento. É esperado que no Estado Democrático de Direito se efetive a juridicidade em sua concepção significativa, constituindo-se, assim, no princípio da equidade. Assim, o Estado Democrático de Direito tem o propósito de objetivar, de acordo com Streck (2004), a juricidade social e a realização da equidade material ou substancial na atual sociedade, se ajustando a efetivação dos direitos fundamentais e a democracia. Esses elementos políticos demandam mutuamente, pois não há direitos fundamentais com ausência da democracia, como não há democracia com a falta de efetivação dos direitos fundamentais.

No modelo concebido pelo Estado Democrático de Direito, ocorreu uma modificação considerável na função a ser exercida pela Constituição, diante das normas constitucionais, as quais possuem total efetividade e força normativa. 
Recorda Streck (2004), a elocução continuamente exposta por Eros Roberto Grau, é defeso mencionar normas programáticas no Estado Democrático de Direito, dando importância ao relevante teor da atual Constituição.

Pertinente recordar que o Estado Democrático de Direito depende, substancialmente, do papel inovador que o Direito se incumbe, o qual transfere para diante do ponto de vista da Constituição como mero dispositivo de ponderação formal das leis de modo global.

Robert Alexy (2005) explica bem expondo que a noção de Democracia deixa de ser apresentada somente como um sistema que contém um regime de tomada de decisão alinhado na ideia de eleição e da regra majoritária, passa a ser entendida como processos fundamentados de acordo com as decisões deliberadas no interno das instâncias.

Por esse motivo, ter uma visão correta de democracia inclui entender não somente as decisões, como também entender suas fundamentações. Introduzir a argumentação na democracia faz com que essa se torne deliberativa.

Nesse cenário, especificamente após a filosofia de Herbert Hart, em concordância com Thomas Bustamante, a moral envolveu a função primordial para a abordagem do Direito. A filosofia jurídica passou a observar o Direito perante uma perspectiva interna de quem aplica e impõe a observância às normas jurídicas, como no Positivismo Jurídico, deixando de entender o Direito através de um olhar externo de espécimes contínuas (BUSTAMANTE, 2012).

Assim, Bustamente (2012) ressalta a relevância da moralidade para a compreensão e legitimidade do Direito. Para o autor, aparenta ser mais razoável que se tenha uma recíproca sujeição entre ambos, mesmo o Direito e a Moral tendo conceitos distintos. É importante o Direito para a Moral superar sua indeterminação cognitiva, bem como é necessária a moral para o Direito legitimar suas decisões.

Desta forma, o neoconstitucionalismo introduziu a moralidade como um de seus aparatos característicos. Bernardo Fernandes (2014) reconhece que as concepções neoconstitucionais, mesmo com divergências, se orientam resumidamente pelas posições de proximidade entre o direito e a moral, sendo para alguns doutrinadores um moralismo jurídico ou uma interpretação moral da constituição que compreende um atual vínculo entre o direito e a moral tendo uma inserção mais frequente nas discussões jurídicas, a Filosofia. 
Por intermédio da constitucionalização do ordenamento jurídico, o Direito e a moral têm se aproximado. A intensa delegação de influência política do Legislativo para a Juridicidade Constitucional advém de tal circunstância.

Nesse segmento, Dworkin (2006) justifica uma interpretação moral da constituição, pelos juízes, em relação às querelas concernentes aos princípios individuais abstratos da carta magna. Garantir atenção e respeito para os cidadãos protegidos pelo Estado, é o objetivo dessa interpretação judicial da Constituição:

O governo deve tratar todos os sujeitos sob seu domínio como tendo igual status político e moral; deve tentar, de boa-fé, tratar todos com igual consideração e deve respeitar todas as liberdades individuais indispensáveis para esses fins, incluindo, mas não se limitando às liberdades especificamente designadas no documento, tais como a liberdade de expressão e de religião. [...] A leitura moral é uma estratégia para juristas e juízes agindo de boa-fé, o que qualquer estratégia interpretativa pode ser. (DWORKIN, 2006, p.7-11).

Mesmo que a interpretação moral, a qual Dworkin menciona, seja referente à Constituição americana, apresenta-se sob a ótica geral sendo usada para interpretar outras Constituições democráticas como fundamento hermenêutico.

Sendo assim, levando em conta a ampliação da jurisdição constitucional, relacionada notadamente à interpretação moral da Constituição realizada pelo Judiciário, será analisado adiante, do ponto de vista hermenêutico, a teoria da Integridade do jus filósofo Dworkin, como a ponderação, nos trâmites da moral, é realizada a interpretação constitucional.

\section{A TEORIA DA INTEGRIDADE DE RONALD DWORKIN}

Na obra "O Império do Direito", Dworkin (2007) descreve a respeito da necessidade do método de interpretação moral da prática jurídica de forma integral. O calcanhar de aquiles em direção à interpretação do Direito é em relação à compreensão do intérprete, de não se misturar com o entendimento pessoal do juiz, uma vez que, de acordo com Dworkin (2007), concerne em uma análise dos princípios em uma determinada sociedade, em que busca a conciliação de preferências voltadas para a interpretação da prática jurídica atual e para uma política em amadurecimento.

A vulnerabilidade hermenêutica do Positivismo Jurídico, para o referido autor, é aparente diante de casos delicados. O direito decidido no passado não é eficaz e absoluto para 
abranger a imensurável enxurrada de casos novos que cotidianamente surgem. Normalmente, para sustentar uma atitude que o juiz pratica, ele procura encontrar alguma justificativa além da garantia do Direito (DWORKIN, 2003).

Do ponto de vista pragmático, a Teoria da Integridade fervorosamente rebate o estímulo ao decisionismo judicial. Essa visão pragmática, segundo Dworkin (2003), incentiva os juízes a deliberar e atuar de acordo com suas convicções. Supondo que essa atuação fosse mais benéfica para a sociedade, chegando mais próximo do que seria uma sociedade equilibrada, satisfeita e justa, comparando a outro meio alternativo que busca compatibilidade com outras deliberações já asseguradas por outros legisladores ou juízes.

Assim, a atividade de interpretação do Direito deve buscar não se alastrar em questões simplesmente políticas, mas também não pode desconsiderar o potencial natural de desenvolvimento do Direito:

O Direito como integridade deplora o mecanismo da antiga visão de que Direito é Direito, bem como o cinismo do novo realismo. Considera essas duas visões como enraizadas na mesma falsa dicotomia entre encontrar e inventar o Direito. Quando um juiz declara que um determinado princípio está imbuído no Direito, sua opinião não reflete uma afirmação ingênua sobre os motivos dos estadistas do passado, uma afirmação que um bom cínico poderia refutar facilmente, mas, sim, uma proposta interpretativa: o princípio se ajusta a alguma parte complexa da prática jurídica e a justifica; oferece uma maneira atraente de ver, na estrutura dessa prática, a coerência do princípio que a integridade requer (DWORKIN, 2003, p. 228).

Relevante mencionar que o autor estende seu entendimento, usando a metáfora do romance em cadeia, para explanar que a interpretação do Direito se equipara à elaboração de um romance, onde o escritor adquire o compromisso de escrever um capítulo de um livro, já começado por terceiros. Assim, para a atividade interpretativa ser a mais apropriada, é necessário levar em conta o que já foi escrito (DWORKIN, 2007).

Consequentemente, encontrar a decisão mais razoável em cada novo caso concreto para a querela jurídica que aparece, impõe ao juiz atuar como se existisse somente uma resposta certa. Diante disso, não pode ser definitiva e nem imutável a resposta vista como certa pelo julgador. Longe disso, a interpretação deve ser momentânea e sempre aperfeiçoada para cada caso concreto. Dworkin (2007, p. 287) observa que:

Não devemos supor que suas respostas às várias questões que se lhe apresentam definem o direito como integridade como uma concepção geral do direito. São as respostas que, no momento, me parecem as melhores. Mas o direito como 
integridade consiste numa abordagem, em perguntas mais que em respostas, e outros juristas e juízes que o aceitam dariam respostas diferentes das dele às perguntas colocadas por essa concepção de direito. Você poderia achar que outras respostas seriam melhores (eu também, depois de alguma reflexão).

Observa-se que o autor advoga por uma democracia constitucional que defende que a Jurisdição Constitucional pode atuar para proteger os direitos fundamentais das minorias. Neste sentido, propõe uma leitura moral a respeito dos direitos fundamentais na condição de desvelar a moralidade política da comunidade, mas que não significa, de maneira alguma, uma decisão que contemple uma visão moralista da sociedade ou dos juízes, aplicadores de tais direitos na presença de casos apresentados.

De acordo com Dworkin (2007), os critérios morais intervêm nas decisões judiciais, principalmente quando se interpreta a Constituição, na medida em que esta prevê instâncias que impõem limites morais a quaisquer leis que possam ser validamente criadas em determinado país. Da mesma forma, as limitações impostas pelos direitos fundamentais aos Poderes Públicos constituem restrições morais.

Ante o exposto, a Teoria da Integridade almeja se opor à arbitrariedade judicial, ao decisionismo e ao subjetivismo. Os estudos de Dworkin se contrapõem aos ideais do Pragmatismo e do Positivismo Jurídico que, perante a um caso complexo, ficam os juízes sem base para resolver.

De acordo com Dworkin (2003), os juristas admitem a ideal compreensão da integridade, buscam decidir situações complexas e encontrar, um grupamento razoável de princípios sobre direito e deveres dos indivíduos, adequando-os a interpretação da doutrina jurídica e da organização política da sua sociedade.

Assim, o intérprete não pode praticar uma atividade interpretativa do ponto de vista metafísico, se desprendendo de suas pré-compreensões. Contudo, ocorrendo em existir précompreensões que, impreterivelmente impulsionariam na interpretação, não implica que quem irá interpreta-las deverá recusá-las. Corrobora Bernardo Fernandes (2014) que a Teoria da Integridade remete ao entendimento de Gadamer. O qual defende que em uma interpretação isenta de discricionariedade pessoal, os juízes devem colocar duvidas em suas précompreensões.

$\mathrm{Na}$ verdade, o horizonte do presente está em processo de constante formação, na medida em que estamos obrigados a pôr à prova todos os nossos preconceitos. Parte dessa prova é o encontro com o passado e a compreensão da qual nós mesmos 
precedemos. O horizonte do presente não se forma à margem do passado. Nem mesmo existe um horizonte do presente por si mesmo, assim como não existem horizontes a serem ganhos. Antes, compreender é sempre o processo de fusão desses horizontes presumivelmente dados por si mesmos. Nós conhecemos a força dessa fusão sobretudo de tempos mais antigos e de sua relação para consigo mesmos e com suas origens. A fusão se dá constantemente na vigência da tradição, pois nela o velho e o novo crescem sempre juntos para uma validez vital, sem que um e outro cheguem a se destacar explicitamente por si mesmos (GADAMER, 1999, p. 457).

Para Bernardo Fernandes (2014), o juiz Hércules, oriundo da Teoria da Integridade, requer do intérprete o comprometimento de pôr em questionamento suas pré-compreensões em uma interpretação harmoniosa com princípios, considerando o passado, o presente e o futuro das comunidades. Nesta perspectiva, Fernandes (2014, p. 195-196) defende que:

Para o jurista e filósofo norte-americano, [...] o direito deve ser lido como parte de um empreendimento coletivo e compartilhado por toda a sociedade. Os direitos, assim, seriam frutos da história e da moralidade, no sentido de que observam uma construção histórico-institucional a partir do compartilhamento, em uma mesma sociedade, de um mesmo conjunto de princípios e o reconhecimento de iguais direitos e liberdades subjetivas a todos os seus membros (comunidade de princípios). Isso implica reconhecer que todos que pertencem a uma mesma sociedade necessariamente compartilham de um mesmo conjunto de direitos e deveres básicos; direito inclusive de participar da construção e da atribuição de sentido a esses direitos, seja na seara do Poder Legislativo, seja na seara do Poder Judiciário.

Sendo assim, a integridade, que amplia a interpretação moral da Constituição, em relação a igualdade de atenção e respeito aos indivíduos, concebida por Dworkin, não induz a reflexões privativas do Direito.

Waldron (2003) considera irrelevante a questão da objetividade moral por entender como arbitrária a decisão dos juízes relativas à moral. Assim, verifica-se que, embora relacionado à questão de princípios, os juízes divergem um do outro. Em seguida, serão analisadas as ponderações de Jeremy Waldron.

\section{O CONSTITUCIONALISMO DE JEREMY WALDRON}

Waldron (1999) descreve que a ligação entre Direito e moral é recusada no Positivismo Jurídico. E essa recusa pode ser no intuito de afastar a clareza da lei advinda da obscuridade que os antirrealistas associam com opiniões morais acerca de justiça. Em geral, a ação de criar leis, para os positivistas, gera a compreensão da moralidade e, a partir do momento que uma norma jurídica é reproduzida pelo Poder Legislativo, nenhuma atividade 
consecutiva de opinião moral deve ser solicitada para reconhecimento, análise e execução (WALDRON, 1999).

Waldron (1999) entende que, se os juízes decidirem a partir de uma moralidade política, existirá claramente na interpretação violação do entendimento. Um julgamento moral de um cidadão caracterizado por sua postura é arbitrário e se torna um julgamento imprevisível, desarrazoado.

De outra forma, Dworkin (2006) compreende que a interpretação moral da Constituição, fundamentada em sua Teoria da Integridade, contrapõe o uso dos valores pessoais dos juristas na interpretação, explica Dworkin (2006, p. 10) que:

\begin{abstract}
Os juízes não devem interpretar a Constituição com base em suas próprias convicções. Eles não devem ler as cláusulas morais abstratas como expressando qualquer julgamento moral particular, não importa quanto esse julgamento os atraia, a não ser que eles o achem consistente em princípio com o desenho estrutural da Constituição como um todo, e também com as linhas dominantes da interpretação constitucional passada feita por outros juízes. Eles devem se considerar como parceiros de outros oficiais, passados e futuros, que juntos elaboram uma moralidade constitucional coerente, e eles devem se assegurar de que a sua contribuição se encaixe com o resto.
\end{abstract}

Procurando exaurir dúvidas que porventura venham a surgir, Dworkin expressa seu entendimento ao dizer que, suponha que um determinado juiz entenda que a justiça genérica proponha equidade econômica, o juiz não conseguiria compreender a norma com igualdade de preservação como igualdade de riqueza, tendo em vista que essa interpretação não seria inserida na história ou execução da Constituição.

De outro modo, para Dworkin (2001), a atividade interpretativa deve ser realizada de dentro da prática e, não por fora dela, para o autor seja qual for o argumento relacionado a clareza de concepções morais será considerado uma compreensão moral, outrossim, qualquer que seja a compreensão inerente as noções interpretativas consistirá em uma argumentação interpretativa.

Ademais, seja qual for a decisão, inevitavelmente será mediada por um entendimento moral. Nesta perspectiva, Dworkin (2001, p. 262-263) esclarece:

Penso que o problema da objetividade, tal como geralmente colocado, é um embuste, pois a própria distinção que poderia dar-lhe significado, a distinção entre argumentos substantivos nas práticas sociais, e argumentos céticos sobre práticas sociais, é falsa. [...] disse que a questão do que independência e realidade constituem, para qualquer prática, é uma questão dentro dessa prática, de modo que 
se os julgamentos morais podem ser objetivos é, por si só, moral, e a questão de se existe subjetividade na interpretação é, por si só, interpretativa. Isso ameaça tornar o ceticismo não inevitável, mas impossível.

Diante disto, Waldron (1999) admite ser desnecessário relevar a objetividade moral, mesmo tendo um fechamento diverso do que expõe Dworkin. Para Waldron (1999), a essência da objetividade aqui trazida é relacionada a situações em que as pessoas defendem que determinadas decisões morais são claramente verdadeiras, ao passo que outras são claramente falsas. Destarte, o quesito da objetividade moral no ponto de vista do autor não é importante. Para ele, ocorrerá arbitrariedade se os juízes instituírem suas próprias convicções morais no caso concreto.

O argumento do autor desenvolve-se na concepção de uma teoria da legislação que, por essência, corrobora com a ideia da maioria e descarta as proposições do controle de constitucionalidade. Waldron (2003), portanto, descreve uma posição de que os juízes ratificam os direitos fundamentais e os elementos de justiça da democracia.

Conduzindo seu argumento, conforme a contemporânea Teoria do Direito, Waldron (1999) aponta a violação da deliberação judicial fundamentada na moral, como desarrazoada e imprevisível, o autor exterioriza que:

\footnotetext{
Nós podemos saber que o juiz vai fundamentar moralmente (por suas próprias visões), mas não saberemos qual será sua posição moral. Ou mesmo que saibamos que ele é, digamos, um utilitarista, nós seremos incapazes de prever sua decisão porque não sabemos o suficiente sobre seus poderes de argumentação ou sobre a informação disponível a ele (WALDRON, 1999, p. 168).
}

Salienta Wadron (1999) que pode alegar, também, a presença desta violação para o direito constitucional americano, considerando ou não a moralidade como clara, objetiva, embora as deliberações judiciais encontrem-se apropriadas e admissíveis, na acepção da ausência de validade política.

Ante o exposto, diz o autor:

\begin{abstract}
Alguns acham que mesmo que os juízes estejam fazendo as decisões morais tão razoáveis e tão previsíveis quanto eles podem, ainda assim, suas decisões seriam ilegítimas politicamente. Cabe ao povo ou aos legisladores eleitos fazer esse tipo de decisão; não cabe aos juízes tomar a determinação de princípio social e valor social em suas próprias mãos. Nesse sentido democrático, arbitrário significa algo como em autoridade ou legitimidade (WALDRON, 1999, p. 168).
\end{abstract}


Contudo, ainda que este não tenha citado Dworkin, critica a tese da resposta correta por compreender que existiria arbitrariedades pela causalidade, pela ausência de razão e pela ilegalidade política na decisão no momento que o Judiciário se utiliza de critérios morais políticos para julgarem determinados casos. Veja:

Juízes diferentes alcançaram resultados diversos mesmo quando todos eles acreditem estar em busca da resposta correta, e nada sobre a ontologia das respostas corretas dá a qualquer deles uma razão para pensar que suas próprias visões são mais corretas do que quaisquer outras (WALDRON, 1999, p. 187).

Além disto, Waldron (1999) declara admissível o fundamento pragmático de que existem imensos dissídios relacionados a questões morais e de que não há consentimento sobre como decidi-las. O autor não considera ser o Poder Judiciário o local ideal para as deliberações constitucionais, então, levando em conta os desacordos sobre questões significativas para a sociedade, expõe que:

\begin{abstract}
As pessoas discordam sobre a publicação de pesquisas de opinião, sobre liberdade de expressão em shoppings, sobre a influência de grupos de interesses especiais e comitês de ação política [...] sobre discurso de ódio, representação étnica. [...] em alguns países, decisões efetivas sobre a estrutura constitucional podem ser tomadas pelas estruturas parlamentares, e, é claro, os parlamentares discordam entre eles sobre o que é desejável. [...] em outros países, essas decisões são tomadas pelo voto popular, em referendos, e acontece, previsivelmente, que as pessoas discordam entre si também. Até mesmo em países como os Estados Unidos, onde a cultura política confia essas questões amplamente às Cortes, os juízes raramente são unânimes. De fato, os juízes discordam tanto quanto qualquer um - e discordam razoavelmente e de boa-fé - sobre a natureza de sua posição de guardião dos valores constitucionais e sobre os comprometimentos de princípio que essa 'posição' supostamente deve incorporar (WALDRON, 1999, p. 279-280).
\end{abstract}

Relevante demonstrar que, para Waldron (1999), embora exista objetividade na moral, da maneira que afirmam os resolutos morais, juristas instituiriam vossas concepções pessoais a respeito da moralidade nas dissidias das partes envolvidas:

Mesmo que o Ceticismo seja rejeitado, mesmo que haja fatos morais que fazem verdadeiros julgamentos verdadeiros e falsos julgamentos falsos, ainda assim o melhor que um juiz pode fazer é impor sua opinião a respeito de tais fatos sobre os infelizes litigantes que vem até ele. Eles terão crenças e opiniões próprias sobre a questão, e mesmo que eles se tornem realistas morais de carteirinha, eles continuarão a perguntar por que a visão do juiz sobre fatos morais deve prevalecer sobre a dos outros. A verdade do Realismo Moral (se ele é verdadeiro) não valida qualquer convicção moral particular de alguma pessoa ou dos juízes. Na melhor das hipóteses, ela altera nosso entendimento sobre o caráter de um desacordo moral sem 
nos mover para nada perto de um entendimento sobre quem está certo e quem está errado (WALDRON, 1999, p. 181).

Deste modo, por cogitar que os juízes divergem entre si como qualquer outro indivíduo, Waldron (1999) constata deficiência de democracia nas deliberações pelas Cortes Constitucionais.

Waldron (2003) defende que pode ser exercido o controle de constitucionalidade a partir das hipóteses de divergência entre o Legislativo e o Judiciário. Impecavelmente o autor coloca no centro do conflito a atuação popular, em que os direitos decorrem da independência moral individual dos que a pleiteiam.

Enfim, de acordo com Dworkin (2007) a interpretação moral da Constituição, realizada por juízes, não se considera em decisões baseada nas próprias convicções, por se tratar de uma análise de princípios. No entanto, Waldron (1999) acha a questão da objetividade na moral irrelevante por existir arbitrariedades, pois os juízes poderiam impor suas deliberações morais para estabelecer soluções as querelas das partes.

Em contrapartida, levando em conta os desacordos morais, políticos e jurídicos, Waldron (2003) demonstra os benefícios da atuação dos indivíduos na elaboração da essência da Constituição por meio das diretrizes da maioria, fundamentando com alicerce na filosofia política do constitucionalismo.

\section{CONSIDERAÇÕES FINAIS}

Neste texto, apresentou-se uma das principais tendências no debate do positivismo jurídico contemporâneo, o papel da jurisdição constitucional. Essa perspectiva foi examinada baseada na teoria de Ronald Dworkin e Jeremy Waldron, filósofos e teóricos do direito que têm concentrado esforços na elaboração de uma teoria do direito democrática, com a finalidade de concretizar os Direitos Fundamentais.

Levando em conta à efetivação das modificações na interpretação, esta deve ocorrer nas situações de execução, legalização e justificação de meios objetivos. A trajetória para a edificação e anuência de uma teoria do direito não é algo tão simples.

A Teoria da Interpretação, consoante debatido, deve ser posta com uma visão segmentada. Os intérpretes precisam estar em similar nível de relevância com as 
metodologias, com os precedentes e com o caso concreto, tendo em vista ser necessário que esses componentes da interpretação estejam incorporados à filosofia do direito.

A Constituição, entendida como um conjunto aberto de regras e princípios, que tem como finalidade concretizar os direitos fundamentais servindo como mecanismo para a efetivação do Estado Democrático de Direito, deve buscar sempre se adequar aos anseios da sociedade.

A jurisdição constitucional, no contemporâneo constitucionalismo, tem como finalidade atuar no equilíbrio da constitucionalidade das leis, pois a obediência à Constituição caracteriza inquestionável e grandioso valor.

De acordo com o exposto, a interpretação moral da Constituição, indicada por Dworkin, considera a concepção de igualdade de atenção e respeito aos indivíduos, uma forma de buscar harmonia com o neoconstitucionalismo. Contudo, o ato de os juízes deliberarem a respeito de questões meramente políticas acarretam diversas críticas de teóricos modernos, tendo como base a questão da legitimidade das decisões em um Estado democrático.

Nesse enquadramento, Dworkin emprega a Teoria da Integridade como fundamento e rechaça que seu entendimento leve os juízes a deliberarem de acordo com suas ponderações próprias. A compreensão hermenêutica estabelece que a integridade apresentada por Dworkin recuse o Positivismo Jurídico e o Pragmaticismo no momento que consente liberdade aos juristas para deliberarem situações complexas.

Dworkin, em sua teoria do direito, como visto, incube relevante importância a atual constitucionalidade, avocando um entendimento particular do direito e encarando a afinidade entre direito e moral que os positivistas, por sua vez, desconsideram.

Por este ângulo, Dworkin, a partir de sua teoria moral e jurídica, propõe ser primordial uma teoria dos princípios na conjectura para uma deliberação justa e coesa. $\mathrm{O}$ direito como integridade retrata significativamente a colaboração de Dworkin à idealização do entendimento de direito.

O direito como integridade, apontado pelo jusfilósofo Ronald Dworkin, tende a criar respostas jurídicas justificáveis com base em padrões políticos instituídos no equilíbrio, analisando o direito a partir desses padrões que atuam como princípios, diferentemente da compreensão dos positivistas, os quais entendem o direito como uma união de regras jurídicas. Assim, é constatado que a teoria da integridade retrata uma concepção coesa do 
direito, marcada pela garantia dos direitos individuais. Fazendo com que o legislador e o julgador defendam a adequação moral do direito.

Diante de fatos difíceis, Dworkin assegura que os direitos dos cidadãos são capazes de erguer-se por meio da pratica social, da decisão judicial, da legislação, bem como das decisões peculiares advindas em detrimento de fatos difíceis.

Assim, frente aos casos difíceis e fazendo uso da metáfora do juiz Hércules, um juiz que admite o direito como integridade, Dworkin menciona que o condão para se utilizar da discricionariedade não é atribuído aos juízes, isto é, não podem conceber um novo direito devido à existência de regras e princípios que podem ser usados para a deliberação da contenda.

Os magistrados realizam uma função significativa na democracia constitucional, tendo em vista que podem delimitar o arbítrio da maioria dos parlamentares através do controle de constitucionalidade, fazendo com que as soluções obtidas por meio do sistema de distribuição de poder político sejam examinadas pelos magistrados mediante igual respeito e atenção.

Então, a teoria de Dworkin designa que a integridade do direito precisa ser verificada por magistrados e por legisladores. É importante que a integridade na jurisdição não frise apenas a coesão, isto é, que a uma decisão abarque todos os casos semelhantes, mas que normas sejam concebidas e interpretadas visando à garantia do devido processo legal e da justiça.

O estudo da Teoria do Direito de Waldron denota uma proposição atenta em acoplar o positivismo jurídico à tradição política normativa, especificamente, a alçada do direito com a legitimidade da legislação democrática e da dignidade, ordenado nos moldes dos processos decisórios do poder legislativo representativo e respeitoso em relação aos desacordos, sendo de grande importância para a filosofia e para a teoria do direito contemporânea.

Dworkin e Waldron acordam em relação à insignificância da objetividade moral, mas chegam a resultados bem distintos. Waldron, conforme apresentado, entende que as deliberações judiciais relacionadas à moralidade consistiriam em violações, sendo considerada objetiva ou não a moralidade. De acordo com ele, na presença de tantos desacordos morais, políticos e jurídicos na sociedade e entre os juízes, não se tem, nas respostas corretas, ratificação de que o entendimento do juiz será o mais adequado e 
esperável, ou seja, que seja mais justo que outro entendimento do cidadão comum, por exemplo, levando em consideração a moralidade.

Partindo do pressuposto que os juízes não são postos em suas funções pela população, Waldron evidencia ilegalidade nas deliberações judiciais relacionada à moralidade, em oposição a Dworkin, o qual entende imprescindível a inserção de deliberações morais pelos juízes por considerar ser condição para uma razoável prática do Direito.

Destarte, a análise de Dworkin concernente à interpretação moral da Constituição, no Estado Democrático de Direito, se depara com inúmeras críticas de Waldron, o qual indica que a validade das deliberações pelo viés político moral ainda não se encontra definitivamente resolvida.

Na esfera da Teoria do Direito, o quesito relevante ao qual se emprega é em que proporção o positivismo jurídico normativo se sustenta como uma teoria do direito ou permanece no campo de estudo da filosofia do direito. Certamente, as teses arroladas por Dworkin e Waldron constituem uma forma de que modo teria que ser a imagem institucional que assegure valores de sociedades livres e democráticas. Indiscutivelmente isso é atribuição da filosofia política e da filosofia do direito, no entanto é imprescindível que essa incumbência seja abarcada também pela teoria do direito.

\section{REFERÊNCIAS}

ÁVILA, Humberto. Teoria dos princípios. São Paulo: Malheiros, 2003.

BARROSO, Luís Roberto. A Nova Interpretação Constitucional: Ponderação, Direitos Fundamentais e Relações Privadas. Rio de Janeiro: Renovar, 2003.

BUSTAMANTE, Thomas da Rosa de. Teoria do Precedente Judicial: A Justificação e a Aplicação de Regras Jurisprudenciais. São Paulo: Noeses, 2012.

CANOTILHO, Gomes. Direito Constitucional. 2. ed. Coimbra: Editora Almedina, 1998.

DWORKIN, Ronald. A justiça de toga. São Paulo: Martins Fontes, 2010.

DWORKIN, Ronald. Uma Questão de Princípio. 1. ed. Tradução de Luis Carlos Borges. São Paulo: Martins Fontes, 2001.

DWORKIN, Ronald. A virtude soberana: a teoria e a prática da igualdade. Tradução de Jussara Simões. São Paulo: Martins Fontes, 2005. 
DWORKIN, Ronald. Domínio da vida: aborto, eutanásia e liberdades individuais. Tradução de Jefferson Luiz Camargo. São Paulo: Martins Fontes, 2009.

DWORKIN, Ronald. Levando os direitos a sério. Tradução de Nelson Boeira. São Paulo:

Martins Fontes, 2007.

DWORKIN, Ronald. O direito da liberdade: a leitura moral da Constituição americana. São Paulo: Martins Fontes, 2006.

DWORKIN, Ronald. O império do Direito. Tradução de Jefferson Luiz Camargo. São Paulo: Martins Fontes, 2003.

FERNANDES, Bernardo Gonçalves. Curso de Direito Constitucional. 6. ed. Salvador: Juspodivm, 2014.

GADAMER, Hans-Georg. Verdade e Método: Traços fundamentais de uma hermenêutica filosófica. 3. ed. Petrópolis: Vozes, 1999.

GADAMER, Hans-Georg. Verdade e Método I. 5. ed. Petrópolis: Editora Vozes, 2003.

REIS, Jane. Interpretação Constitucional e Direitos Fundamentais. Rio de Janeiro: Editor Renovar, 2006.

ROBERT, Alexy. Teoria da Argumentação Jurídica. São Paulo: Landy Editora, 2001.

STRECK, Lenio Luiz. Jurisdição constitucional e hermenêutica: uma nova crítica do direito. Rio de Janeiro: Forense, 2004.

STRECK, Lenio Luiz. Hermenêutica Jurídica e(m) Crise: Uma Exploração Hermenêutica da Construção do Direito. 6. ed. Porto Alegre: Livraria do Advogado, 2004.

WALDRON, Jeremy. Law and Disagreement. New York: Oxford University Press, 1999.

WALDRON, Jeremy. A dignidade da legislação. Tradução de Luís Carlos Borges. São Paulo: Martins Fontes, 2003. 